ЦИВІЛЬНЕ ПРАВО ТА ЦИВІЛЬНИЙ ПРОЦЕС; СІМЕЙНЕ ПРАВО;

МІЖНАРОДНЕ ПРИВАТНЕ ПРАВО

CIVIL LAW AND CIVIL PROCESS; FAMILY LAW; INTERNATIONAL PRIVATE LAW

УДК 34

DOI: $10.26565 / 2075-1834-2020-30-04$

\title{
LEGAL PERSPECTIVE OF FEMALE CIRCUMCISION: STUDY OF WOMAN RIGHTS TO ACCESS INFORMATION OF SEXUAL HEALTH IN INDONESIAN AND SOMALIA
}

\author{
Lanny Ramli, \\ Faculty of Law, \\ Universitas Airlangga, \\ Surabaya, Indonesia, \\ e-mail: lannyramli10@gmail.com
}

orcid: https://orcid.org/0000-0002-3014-2363

ANNOTATION: Introduction: Female circumcision is a controversial practice in some countries, including Indonesia. The female circumcision also occurs in Somalia and has impact of medical complication.

Objective: This study aims to know the implication of female circumcision in Indonesia, especially in Situbondo, Surabaya and Bangkalan with implication of female circumcision in Somalia.

Methods: Quantitative methodology is used as the methodology, while the samples are taken through random sampling and given questionnaire, interview and comparison with Somalia.

Results: The finding showed that most women are still does not know about the function of female circumcision in Indonesia and Somalia, they only following the tradition within their community. The patriarchy culture that view woman as a lower creature makes woman cannot get her right in asking about reproductive health. In Somalia, there are impact of circumcision with reproductive health and many complications with health. It even considered as taboo and unnecessary. Female circumcision that firstly legalized by the Health Minister is now prohibited due to health problem. Therefore, female circumcision is no longer legal in Indonesia meanwhile in Somalia is legal in their government.

Conclusion: In Indonesia, female as a part of society did not have any rights on their own self. Their life is depend on the tradition which sustain until present and will be continued for next generation. The tradition is often spread within the religious belief and vice versa. Therefore, the practice of female circumcision is still happening in three regions, including Surabaya, Bangkalan and Situbondo. Meanwhile In Somalia, female as a part of society who has any rights on their own self. In Somalia, female circumcision was supported by society and government in Somalia.

KEY WORDS: Female Circumcision, Health Awareness, Risk of Medical, Reproductive health, Legal Circumcision.

\section{ПРАВОВА ПЕРСПЕКТИВА ЖІНОЧОГО ОБРІЗАННЯ: ДОСЛІДЖЕННЯ ПРАВ ЖІНОК НА ДОСТУП ДО ІНФОРМАЦІЇ ПРО СЕКСУАЛЬНЕ ЗДОРОВ'Я В ІНДОНЕЗІЇ ТА СОМАЛІ}

\author{
Lanny Ramli, \\ Юридичний факультет, \\ Університет Airlangga, \\ Сурабая, Індонезія \\ e-mail: lannyramli10@gmail.com
}

orcid: https://orcid.org/0000-0002-3014-2363

АНОтАЦІя: Bcmyn: Обрізання жінок - суперечлива практика в деяких країнах, включаючи Індонезію. Обрізання жінок також відбувається в Сомалі і має наслідком медичне ускладнення.

Мета: Це дослідження має на меті дізнатися про наслідки обрізання жінок в Індонезії, особливо в Ситубондо, Сурабаї та Бангкалані, про наслідки обрізання жінок у Сомалі.

Методи: Кількісна методологія використовується як методологія, тоді як вибірки беруться шляхом випадкової вибірки та дається анкета, інтерв'ю та порівняння з Сомалі.

Результати: Показали, що більшість жінок досі не знають про функцію обрізання жінок в Індонезії та Сомалі, вони лише дотримуються традицій у межах своєї громади. Культура патріархату, яка розглядає жінку як нижчу істоту, робить жінку неможливою, щоб правильно поставити питання про репродуктивне здоров'я. У Сомалі спостерігається вплив обрізання на репродуктивне здоров'я та багато ускладнень на здоров'я. Це навіть вважається табу і непотрібним. Обрізання жінок, яке вперше було узаконено міністром охорони здоров'я, зараз заборонено через проблеми зі здоров'ям. Таким чином, обрізання жінок в Індонезії вже не є законним, тим часом як у Сомалі закон у їхньому уряді. 
Висновок: В Індонезії жінки як частина суспільства не мали власних прав. Їхнє життя залежить від традиції, яка зберігається донині і буде продовжена для наступного покоління. Традиція часто поширюється в межах релігійних вірувань і навпаки. Тому практика обрізання жінок все ще відбувається у трьох регіонах, включаючи Сурабаю, Бангкалан та Сітубондо. Тим часом у Сомалі жінка як частина суспільства, яка має будь-які права на себе. У Сомалі обрізання жінок було підтримане суспільством та урядом Сомалі.

КЛЮЧОВІ СЛОВА: Обрізання жінок, обізнаність про стан здоров’я, ризик медичного обслуговування, репродуктивне здоров'я, юридичне обрізання.

\title{
ПРАВОВЫЕ ПЕРСПЕКТИВЫ ЖЕНСКОГО ОБРЕЗАНИЯ: ИССЛЕДОВАНИЕ ПРАВ ЖЕНЩИН НА ДОСТУП К ИНФОРМАЦИИ О СЕКСУАЛЬНОМ ЗДОРОВЬЕ В ИНДОНЕЗИИ И СОМАЛИ
}

\author{
Lanny Ramli, \\ Факультет права, \\ Университет Airlangga, \\ Сурабая, Индонезия, \\ e-mail: lannyramli10@gmail.com
}

orcid: https://orcid.org/0000-0002-3014-2363

АННОтАЦИЯ: Введение: Женское обрезание - противоречивая практика в некоторых странах, включая Индонезию. Женское обрезание также происходит в Сомали и имеет осложнения со стороны здоровья.

Цель: это исследование направлено на изучение последствий женского обрезания в Индонезии, особенно в Ситубондо, Сурабае и Бангкалане, с последствиями женского обрезания в Сомали.

Meтодbl. В качестве методологии используется количественная методология, тогда как образцы берутся путем случайной выборки и анкеты, интервью и сравнения с Сомали.

Pезультаты: открытие показало, что большинство женщин все еще не знают о функции женского обрезания в Индонезии и Сомали, они только следуют традициям в своей общине. Патриархальная культура, которая рассматривает женщину как низшее существо, заставляет женщину не иметь права спрашивать о репродуктивном здоровье. В Сомали обрезание сказывается на репродуктивном здоровье и имеет множество осложнений. Это даже считалось табу и ненужным. Женское обрезание, которое сначала было разрешено министром здравоохранения, теперь запрещено из-за проблем со здоровьем. Таким образом, женское обрезание больше не является законным в Индонезии, в то время как в Сомали законно в их правительстве.

$B$ вывод. В Индонезии женщины как часть общества не имели никаких прав на себя. Их жизнь зависит от традиций, которые сохраняются до сих пор и будут продолжены для следующего поколения. Традиция часто распространяется в рамках религиозных верований и наоборот. Таким образом, практика женского обрезания попрежнему применяется в трех регионах, включая Сурабайю, Бангкалан и Ситубондо. Между тем в Сомали женщина как часть общества имеет какие-то права на себя. В Сомали женское обрезание было поддержано обществом и правительством Сомали.

КЛЮЧОВІ СЛОВА: женское обрезание, осведомленность о здоровье, медицинский риск, репродуктивное здоровье, правовое обрезание.

Introduction

The history of gender differences, between male and female, was happened from a long time ago and occurred through a very long process. The word "gender" has been entered the vocabulary in every discussions and writings related to social change. However, people are sometimes cannot differentiate between gender and sex. They tend to differentiate gender in stereotypes between female and male, and consider it is similar to sex. In this research, the researcher will describe about the definition of gender in Indonesia and In Somalia and also background of female circumcision from both country.

\section{IN INDONESIA}

Gender defines as social and cultural construction within society for male and female while sex is a term for biological context to identify between male and female, including the body hormone, physical anatomy, reproduction and other (Lestari, 2015; Umriana, Fauzi, \& Hasanah, 2016). Trianto added that gender refers to the differentiation of characteristic, role, function and status between woman and man that not based on the sex but rather on social and cultural relation influenced by the structure of community (Trianto, 2012). Gender is not only directed to differentiate between woman and man biologically, but for ideological and material relationship on the existence of both (Umriana et al., 2016). Rachma dewi explained that gender has strong relationship with equality (Rachmadewi, 2000). Gender equality means equality between man and woman to get chance and rights as a human to participate in some activities, such as politics, economics, education and others (Pasaribu, 2006).This concept of equality is directed to the equality of human in life to get the same right. As stated by Universal Declaration of Human Rights that all human being has right since their born until die or during their lifetime (Ramli, 2019). No matter whether female or male, all human being has right to get the same position for a chance in education, health and others. 
However, in society, people are still viewing women have lower level than men. This assumption leads women to have difficulty in accessing information about reproductive health. The activities of accessing information and/or knowledge of reproductive health and access to reproductive health are considered taboo and unnecessary, as in female genital cutting/circumcision (FGC). FGC is a traditional cultural practice that cut or alter the external female genital organs. The practice of FGC can be found in communities in Africa, Middle East, Asia and South America. United Nation reported that Indonesia is included in countries that still practice on FGC (Natsir, 2003). Indonesia, especially in Java, is still familiar with FGC. For most people in Banten, circumcision or genital cutting must be performed at 40 days after birth or if the genital is not yet ready, it is recommended to cut it on age 2-3 months (Fauziyah, 2017). People in Lampung also has similar tradition with Banten, female circumcision is performed when the woman aged 2-3 years. They believed that women who are not circumcised will look less beautiful and luminous (Santi, 2006). The same thing is also shown by Banjar community who engage female circumcision activities at 40 days after born by reason of following the existing tradition and has been done for generations. They assume that it is not perfect when the existing tradition is not continued by the next generation. The tradition should be continued due to maintain the value (Nurdiyana, 2010). Another practice in female circumcision or genital cutting is performed by community in Yogyakarta. They practice the female circumcision as a form of Islamic religious worship. However, there is no sanction for those who does not want to perform the circumcision. Meanwhile in Madura, female circumcision is performed with aim as ritual of Islamic belief and has no relation with the cultural history (Putranti, 2005).

Based on research conducted by Nantabah, Laksono, \& Tumaji (2015), it can be seen that female circumcision is mostly done in West Java Province (14.7\%), North Sumatera Province (8.1\%), and East Java (7.3\%). Female circumcision rates in West Java and East Java provinces are influenced by Kyai (religious leader) and charismatic clerics. Most of Indonesian people, do the FGC due to religious reason. It is believed that female circumcision is done to restrain women's lust. In contrast, Dr. Sharifa Sibani who undertook a study on sexual behavior of circumcised women, found that there was no difference in sexual arousal or libido between circumcised women and uncircumcised women (Smita, 2013).

The practice of female circumcision or female genital cutting is still controversial. According to United Nation Commission for Human Rights, FGC is recognized as a violation of women's right in health, security, and physical integrity. It confirms as a violence against women which threat to reproductive health (Imelda, Djamilah, Kartikawati, Mahendro, \& Ratri, 2018). UN also move a campaign of zero tolerance toward FGC practices, as there are more than 150 million of women had suffer from the genital cutting (Natsir, 2003). Hence, this study aims to know whether the female circumcision is legal or illegal.

In 1981, 2497 subjects (comprising women and girls) were interviewed in Somalia, In Pia's research, there are presented the principle cultural trends which are connected with the custom and which have arisen from the research. The type of circumcision does not seem to be influenced by some environmental variables. It is primarily determined by the population of the individual region. Infibulations is accepted to the greatest extent by the pastoral populations of the middle/northern regions. In the southern regions amongst rural populations or population with a cattle/cultivation economy, there are also attenuated types of circumcision: sunna and clitoridectomia (20 to $30 \%$ ).

\section{IN SOMALIA}

Meanwhile in Somalia, female circumcision is showed in three different ways for instance; a. The sunna type is analogous with male circumcision and consists of the excision of the prepuce of the clitoris; $b$. The clitoridectomy type consists of the excision of the clitoris sometimes with parts of the minor labia; c. The excision and infibulation operation means excision of the whole clitoris, the minor labia and the internal faces of the major labia. The remains of the major labia are then stitched together and a small opening left at the lowermost part of the vulva. Sometimes this opening is measured by a piece of wood which is about thickness of a match stick. Urine and menstrual blood drible through that opening and this entails serious consequences to the gynaecological health of the woman. Immediate medical complications are frequent and often serious. They are haemorrhagic. Infection and urinary retention.

\section{Method}

This research using quantitative methodology. Quantitative methodology is conducted for testing objective theories by examining the relationship among variables. The data are gained using questionnaire and depth interview due to deepen the previous data from questionnaire that determine the knowledge and understanding about female circumcision related with tradition and human rights. This study is applicable using purposive random sampling and questionnaire for 300 respondents, consisting of the mothers, the midwives, Kyai (religious leader), and community leaders. The location is chosen based on the locations that often practice female circumcision, including; Surabaya, Situbondo, and Bangkalan (Madura).

The study is conducted by elaborating the reason of why a baby girl should be circumcised, and the consequence if she is not circumcised related tradition and human right. The data analysis is performed not only by statistic form or statistic model but also by socio-legal model. The data are obtain in some location, through 
female that conduct circumcision, midwives, community leaders, and religious leaders. The questionnaire can be seen in table 1 below;

Table 1. Questionnaire on Female Circumcision

\begin{tabular}{|c|c|c|}
\hline \multicolumn{3}{|r|}{ Questionnaire } \\
\hline No & Respondent & Question \\
\hline 1. & Mother & $\begin{array}{l}\text { 1. How many years in marriage? } \\
\text { 2. How many children does she have? } \\
\text { 3. How old the daughter? } \\
\text { 4. Have you ever heard about female circumcision? } \\
\text { 5. If it is yes, from whom did you hear about female } \\
\text { circumcision? } \\
6 \text {. Have you ever circumcised your baby girl? } \\
\text { 7. If you refuse to circumcise your baby girl, how does the } \\
\text { society react? } \\
\text { 8. If you refuse to circumcise your baby girl, how does the } \\
\text { religious leader react? } \\
\text { 9. If you refuse to circumcise your baby girl, how does the } \\
\text { community leader react? } \\
\text { 10. Do you know that female circumcision is prohibited by the } \\
\text { Government? }\end{array}$ \\
\hline & Answer's Mother & $\begin{array}{l}\text { 1. } 12 \text { years } \\
\text { 2. } 10 \text { childrens } \\
\text { 3. } 10 \text { years } \\
\text { 4. Yes, I ever heard } \\
\text { 5. From the specialist doctor of obgyn } \\
\text { 6. Yes, I ever } \\
\text { 7. Society will assume that the baby girl is not clean or pure } \\
\text { 8. They asked me for circumcision my baby girl } \\
\text { 9. They asked me for circumcision my baby girl } \\
\text { 10. No }\end{array}$ \\
\hline 2. & Midwives & $\begin{array}{l}\text { 1. How many years worked as midwives? } \\
\text { 2. How many baby girls' circumcision had been done? } \\
\text { 3. Have you ever heard about female circumcision? } \\
\text { 4. If it is yes, from whom did you hear about female } \\
\text { circumcision? } \\
5 \text {. What is the purpose of female circumcision? } \\
6 \text {. How is your respond if the family or the mother refuse to } \\
\text { circumcise the daughter? } \\
\text { 7. If you are refusing female circumcision, how is the reaction } \\
\text { of religious leader? } \\
8 \text {. If you are refusing female circumcision, how is the } \\
\text { reaction of community leader? } \\
\text { 9. Do you know that female circumcision is prohibited by the } \\
\text { Government? }\end{array}$ \\
\hline & Answer's midwives & $\begin{array}{ll}\text { 1. } & 10 \text { years } \\
\text { 2. } 2 \text { childs } \\
\text { 3. Yes } \\
\text { 4. From the religious leader } \\
\text { 5. To purify our self } \\
\text { 6. My religious leader will angry } \\
\text { 7. My religious leader will angry } \\
\text { 8. My community leader will angry } \\
\text { 9. No }\end{array}$ \\
\hline 3. & Community Leader & $\begin{array}{l}\text { 1. How many years as a leader? } \\
\text { 2. Have you ever heard about female circumcision? } \\
\text { 3. If it is yes, from whom did you hear about female }\end{array}$ \\
\hline
\end{tabular}




\begin{tabular}{|c|c|c|}
\hline & & $\begin{array}{l}\text { circumcision? } \\
\text { 4. What is the purpose of female circumcision? } \\
\text { 5. How is your respond if the family or the mother refuse to } \\
\text { circumcise the daughter? } \\
\text { 6. Do you know that female circumcision is prohibited by the } \\
\text { Government? }\end{array}$ \\
\hline & $\begin{array}{l}\text { Answer's Community } \\
\text { Leader }\end{array}$ & $\begin{array}{l}\text { 1. } 40 \text { years } \\
\text { 2. Yes } \\
\text { 3. Specialist doctor obgyn } \\
\text { 4. To purify our self } \\
\text { 5. I will give them the advantages about the circumcision } \\
\text { 6. yes }\end{array}$ \\
\hline 4. & Religious Leader & $\begin{array}{l}\text { 1. How many years as a religious leader? } \\
\text { 2. Have you ever heard about female circumcision? } \\
\text { 3. If it is yes, from whom did you hear about female } \\
\text { circumcision? } \\
\text { 4. What is the purpose of female circumcision? } \\
\text { 5. How is your respond if the family or the mother refuse to } \\
\text { circumcise the daughter? } \\
\text { 6. Do you know that female circumcision is prohibited by the } \\
\text { Government? }\end{array}$ \\
\hline & $\begin{array}{c}\text { Answer's Religious } \\
\text { Leader }\end{array}$ & $\begin{array}{l}\text { 1. } 62 \text { years } \\
\text { 2. Yes } \\
\text { 3. From ancestor of religious leader } \\
\text { 4. Doing shari'a to purify our self. } \\
\text { 5. I will give them the advantages about the circumcision } \\
\text { 6. Yes. }\end{array}$ \\
\hline
\end{tabular}

\section{Result and Discussion}

\section{INDONESIA}

\section{In Indonesia Female has no Right to Access Information about Female Circumcision}

Female has equal rights to access to justice, but there are some things that cause female difficult to access justice in obtaining information on reproductive health, such as;

- Females are considered stupid by male, hence they do not need to be given an explanation about the reproductive health matter. Even if they ask about it, it will be answered casually.

- Males are seen females have lower degree than male. They considered cheap and deserve to be seduced, which may lead to be the victim of sexual harrasment.

- The habit of placing the portion or position of female as the second citizen, konco wingking(friend behind), and swarga katut, neraka nunut (her heaven and hell is depend on her husband), thus females have no self-existence and become afraid to ask on things related to the case.

- The view of female above indicate that females are not educated enough. Thus they have no bravery to question about things that happened to them.

- There are patriarchal culture that requires female as subject to male's 'power'.

Based on population projection data from the Central Bureau of Statistics (Biro Pusat Statistik / BPS), the current population of Indonesia is more dominated by productive age group, that is, between 15-64 years. The Central Bureau of Statistics distinguishes the productive age population into 2 categories; very productive age ranged from 15-49 and productive age ranged from 50-64. The number of women within the very productive age category has reached 69.4 million, while for the productive age only reached 16.91 million. The statistic can be seen in table 2 below;

Table 2. The Central Bureau of Statistics of East Java 2017

\begin{tabular}{lll}
\hline Town/Region & Male & Female \\
\hline Situbondo & 326.500 & 343.213 \\
\hline Surabaya & 1.406 .683 & 1.441 .900 \\
\hline Bangkalan & 455.710 & 498.595 \\
\hline
\end{tabular}


Based on the table 2 above, it can be seen that the population in three regions are dominated by female. Female, as part of society, must have vision, mission and strategy to have equal rights and obligations with men or called as gender equality. There are several points that female are struggling through strategies for the future (Afkhami, 2008), such as;

- Insisting that no one, man or woman, may claim the right to monopoly interpretation of human beings or right to force others to accept a particular ruling about any religion. The upshot of this position is that women ought not to be forced to choose between freedom and God. The same applies to claims on behalf tradition.

- Insisting that international governmental and non-governmental organizations, national-states, civil society organizations, as well as national and multinational corporations, decide their policies about international, national and local issues in cognizance of the universal rights of women.

- Educating the decision-makers at all levels about the plight of women and the reason why they should try to shape their decisions to help women achieve their internationally recognized rights

- Holding governments and organizations responsible for the effect on women of political, social, economic and cultural choices they make nationally or internationally.

Sex is a physical or biological distinction between female and male, while sexuality involves a wide variety of dimensions, including the dimensions of biological, social, psychological and cultural. Female in patriarchal society have no right to gain sexual knowledge. As Walby (1990) cited in Hakim (2016) that patriarchy is a social structures system and practices used by men to dominate, oppress and exploit women. Her sex life is even turned off with hereditary notions and customs, such as in circumcision. Female circumcision is believed to decrease female libido(Farida, Elizabeth, Fauzi, Rusmadi, \& Filasofa, 2017; Fauziyah, 2017)and make females more honorable. Females are not given the opportunity to know the benefits of the circumcision but to follow the society's habit. Based on the interview, most of the females' respondent did not know about the function of circumcision for their selves. Most of them only follow the tradition within their community.

Prohibition in Female Circumcision

The right of every person to earn a decent living is closely linked to human rights. The notion of three generations of human rights was proposed by a French lawyer named Karel Vasak. These three generations of human rights are the new outlook replacing the previous view of classical rights which inspired by the three normative themes of French Revolution, including;

a. The first generation of civil and political rights (liberte)

b. Second generation of social and cultural rights (egalite)

c. The third generation of rights of solidarity (fraternite)

The third generations are interconnecting and re-conceptualizing the value demand which relates to the previous human rights generations. There are six of human rights that are being accused, namely;

1. The right to self-determination in the political, economic, social and cultural fields;

2. The right to economic and social development;

3. The right to participate and utilize the "common heritage of mankind" (shared space resources, scientific and technical information and progress, and cultural traditions, locations and monuments);

4. The right to peace;

5. The right to a healthy and balanced environment;

6. The right to natural disaster relief.

These are written in Universal Declaration of Human rights especially about life which regulates in Article 25, "each individual has right to live healthy and in good conditions for him/her own self including food, clothes, home, and health care and social business and so forth" (Baut et al, 1988 cited in Ramli, 2019). Therefore, human, either man or woman, has equal right during their lifetime. However, at first, the concept of gender is commonly related with sex which refers to biological identity (Umar, 1999). While nowadays, gender is already defined as the division of the roles and duties between man and woman based on the norms, customs, beliefs and customs (Negara, 2005).

In female circumcision case, the implementation is already legalized by the Ministry of Health. The regulation of female circumcision is written on PERMENKES (Regulation of Health Ministry) Number $1636 / 2010$ which said that female circumcision should be done under the religion, service and profession standard due to guarantee the security and safety of circumcised woman. In this regulation, the Minister of Health has been regulated that circumcision can be done by request or demand and should not be in the form of cuts (genital mutilation) but scratches only. However, even if it is only scratches but it still have potential to cause wounds, bleed and infection. These kind of risks should be notified to the parents before circumcised their daughter.

Along with the development of the era, the Regulation of Health Ministry Number 1636/2010 has been revoked on the Regulation of Health Ministry Number 6/2014. The reasons are as follows:

1. Every action taken in the medical field must be based on medical indications and prove to be scientifically useful; 
2. Female circumcision, until these days, is not a medical action because its implementation is not based on medical indications and has not proven to be beneficial to health;

3. Based on the aspects of Indonesian culture and beliefs, until now, there are still requests for female circumcision to be carried out whose implementation must still pay attention to the safety and health of women who are circumcised, and not to carry out female genital mutilation;

Female circumcision is still done within community from time to time without knowing any definitive knowledge about the circumcision itself. Parents do not know about the benefits and do not see the implementation of circumcision directly. They also never asked the midwife about the circumcision. Mostly, the implementation of female circumcision is done by Dukun (Shaman). The mother of the daughter put trust to dukun to do the circumcision of her daughter since she has emotional relation which arises during the pregnancy massage. Dukun persuade the mother to circumcise her daughter due to reduce the libido and make the daughter has high dignity and beautiful soul (Sakti, 2004). The circumcision is done after two weeks of birth. Dukun comes to bath the baby, take care for the umbilical cord and do the circumcision by rubbing it with turmeric.

The mothers, mid wives, and the other part of society obey the habit of female circumcision for baby girls because of the tradition and religion. The religious leader share on the urgency of female circumcision based on the Hadith, while the community leaders got assumption that female circumcision must be conducted based on the tradition and religion. For most of the societies, tradition is often mixed with religious beliefs and vice versa (Feillard \& Marcoes, 1998)

The matters that make worse the differentiation between female and male is the presumption of public and private. Julia Cleves Mosse stated that one of the most powerful ideologies that stressing gender differences is the division of the world into public and private area. Public areas consisting of public institutions, state, government, education, media, business world, corporate activities, banking, religion and culture which predominantly by male and private predominantly by female.

From this study, it is known that in some community, female do not have power to determine their right. They cannot get any information and knowledge on circumcision by literature or medical information. They also have no right to refuse the circumcise tradition. They only do what the religious and community leader asked due to maintain the tradition, even though the circumcised has been banned by the government.

Knowledge on human rights protection policy regarding the rights of women and children

The application of gender equality requires understanding and knowledge of things related to the fundamental of human rights. In addition, developing the method to implement laws which capable to manage all levels of society is also important considering the community also contributes to the implementation of gender equality. The scope of gender equality is related to access given without differentiation between men and women, including the right to participate, to access health, to feel the benefits of development, and of course related to the national development context that covers the entire development management cycle in both central and regional levels.

There is a relation among the three points of interrelated elements in implementing laws that support gender equality. These points are carried out simultaneously in order to eliminate gender discrimination and provide knowledge on equal rights among communities, and no exception for women. These three points are; (a) law in books, (b) law in action, and (c) law in society. Law in books can be defined by how the law is narrated in existing regulations. Whereas in the implementation, the law changes into law in action. Law in actions is explained by how the law is interpreted and can be implemented by the government. Then in the third point, law in society is a law that should be able to be interpreted and implemented by the community as a series of regulations and in collaboration with government officials in the implementation.

In response to this, the implementation of gender equality requires the intervention of many parties who support each other and work together to eliminate the existence of gender discrimination and restrictions on rights on the basis of gender. In an effort to implement gender equality, the State Administration Agency needs to ensure the implementation through the Leadership Committee, policies, institutions, human resources, budgets, data and public participation. The linkage of the whole thing will support each other's efforts to implement gender equality that is able to be accepted by all communities and government.

Understanding these conditions, the implementation of gender equality activities requires an understanding of the community so that the law or regulation runs as it should run. Providing equal access rights without distinguishing male and female gender, giving rights to the field of nation-building and a fair state is the goal of gender equality.

The implementation of regulations based on law in the legislative is regulated in written regulations and narrated based on the applicable legal articles in the government environment. The scope of the area affected by the regulation is regulated based on the issuance of applicable regulations. In the implementation of gender equality, the implementation of regulations is regulated more carefully through Government Regulations. In its implementation, the government can implement regulations through education and training institutions to the community. This activity is supported by the existence of research and development of science that can be used and applied by the community well. Educational institutions in their implementation can integrate gender 
perspectives into the education curriculum early and conduct research on gender perspectives in the field institutions of each agency.

In this regard, research on a gender perspective provides an opportunity for agencies to be able to provide documentation about the diversity of data obtained regarding the pre-conditions and conditions after the application of gender equality. Data that is uniquely categorized as disaggregated data provides a reference to the method of implementing the law so that it can be applied optimally. The implementation of gender equality is based on various principles that support each other's conditions. Community participation is also one of the principles needed to implement gender equality that is not detrimental to one group that is distinguished by gender.

The act of circumcision in women is one proof that the community is still legalizing and does not understand the actions that violate the rules and human rights, especially women. In the process of improving the quality of life of the community and creating a just and non-discriminatory community life, regulations and information on the knowledge of gender equality need to be carried out to the community. However, community participation is needed to eliminate harmful actions in any case, especially health and in order to improve the quality of society. What's more, an action that is not based on knowledge and harms society requires enforcement that is able to eliminate it. The regulations contained will only be a narrative that cannot eliminate the act of gender discrimination without actual action. The implementation of the elimination of discrimination requires actual implementation based on written regulations by the government and based on the actual conditions of the surrounding community.

Different regions require different legal implementation actions. The circumstances or conditions of different communities certainly require different legal handling. Law enforcers need cooperation with the community in order to implement gender equality. The community needs to be given knowledge or counseling on equality that can increase the welfare level of community life. The State Organizing Agency in carrying out gender mainstreaming certainly needs to conduct a study of the formulation of work policies based on community conditions, set limits and budget allocations that are in accordance with the planned policy conditions so that the allocated funds can be used properly.

As a part from the result of this study in Bangkalan, Knowledge of the law for implementing female circumcision $69 \%$ said it was mandatory. Taken from the arguments of hadith which are considered to be very strong so circumcision of girls must be carried out. While $31 \%$ said their arguments were weak so they said they were not compulsory but because it had become a tradition, circumcision of girls was still carried out. As the data above shows that all informants carry out circumcision in girls. Proposals that are considered to be very strong are sources of information used by the community to strengthen the practice of circumcision.

In terms of ordering circumcision, the strongest is $83 \%$ Grandpa / grandmother, because circumcision has been a tradition carried out for generations, and is considered the most knowledgeable, then the one who rules the circumcision is uncle / aunt, then the parents themselves ordered circumcision. In addition, medical personnel / traditional birth attendants will immediately carry out circumcision or notify the parents of girls born to be circumcised. What's interesting is that the desire for circumcision also occurs in girls themselves, this is likely because the environment requires all girls to be circumcised. An order is information that must be carried out if it is not grandparents, parents, uncles / aunts, or medical personnel.

Otherwise, in Surabaya area, knowledge of the law on the practice of circumcision says that there are $77 \%$ compulsory, this is because the understanding of the practice of circumcision is not a tradition. Whereas those who say compulsory law as much as $23 \%$ are people who carry traditions from their origin. In addition, the educational background of parents of girls who are already high enough to finish high school or university allows parents not to practice circumcision. The actor who carries out circumcision in the city of Surabaya is a doctor because $76 \%$ of mothers give birth in hospitals often parents do not understand that their daughters have been circumcised. Whereas midwives often circumcise because of the request of parents who have a tradition of circumcision in girls. Paramedic in Surabaya consider following parental willingness more important.

Beside it in Situbondo, the knowledge of the law of circumcision for girls is prohibit, almost all informants are $100 \%$. But this is due to a very strong tradition brought from the area of origin. By carrying out the practice of circumcision, the community considers that there is a strong cultural attachment to the area of origin, they say that there are descendants from Madura. And this is their pride. Almost all the informants in the Situbondo area were not aware of the law regarding the practice of circumcision for girls, this might be due to the educational background of women who did not graduate from junior high or high school, almost all said they also did not understand why female circumcision was carried out.

Based on the elaboration above, knowledge of the practice of circumcision for girls in the study area does not indicate the existence of medically veiled data. The majority of actors who legalize these actions practice when girls are under five. What's more, the actor behind the action uses a belief system that is obtained down in general. Knowledge of an obligation that must be carried out on the basis of trust, encourages the perpetrator to carry out the practice without any rejection from the surrounding environment because the same surrounding environment also relieves the action. Another factor found was the ignorance of the perpetrators of human rights 
violations committed against their own family members. Given that the majority of actors are family members who have an older age, making family members carry out these actions without questioning cause and effect. Even the actor's family feels that practicing female circumcision is a natural thing and does not adversely affect the child, due to lack of knowledge that there is a danger that threatens the child's condition in the future. The presumption of taboos like the reduction of lust can actually be explained by using the medical world approach, but these actions still have other adverse effects besides only decreasing women's lust. The community feels that they do not understand and do not conduct further studies regarding actions that have actually been regulated in Government Regulations.

Based on this, it is clear that there is a lack of knowledge of people's understanding of applicable laws. Where the applicable law actually regulates a life that is fair and without the violation of human rights against fellow citizens. Regional Government is actually capable of carrying out regulations that are able to provide equal fairness among people without distinguishing gender. The government collaborates with the community to exchange information in response to actions taken in the community based on existing regulations. Understanding and implementing regulations together between government agencies and the community will make the condition of the community comfortable to use as a place of family nation and state.

By applying the three points in the previous discussion, "Law in the book", "Law in action", and "Law in Society", the government and the community work together to apply applicable laws and make the environment more equitable to others. The condition of the community that understands gender equality and is not discriminatory certainly requires knowledge of the ways and actions to be taken. By responding to this, the government provided education along with counseling on gender equality to the community through various activities beginning with policy planning, until implementation ended with evaluation of activities. Adding material to the education curriculum provides fundamental knowledge for children and parents, while providing counseling through village officials and health institutions will play a key role in educating gender equality on families and the surrounding environment.

\section{SOMALIA}

\section{The participants put forward for the rejection of Female Circumcision}

The majority of participants with the exception of one man and one woman (36/38), expressed their rejection of all types of female circumcision. However, different arguments were put forward for the discontinuation of the practice. Chiefly among them were that the practice causes health problems; is not a religious requirement, is a very painful experience with the potential to erode females'sexual feelings; and the social environment in Norway, which is supportive of its discontinuation

The majority of participants agreed that the practice was introduced into their community. Still, they rejected the practice, as they were fully convinced that the practice is un-Islamic. With the exception of one person, the participants unanimously agreed that Female circumcision causes a number of health problems and is not a religious requirement.

Conversely, while most female participants justified their opposition to female circumcision by stating that it is un-Islamic and painful, the majority of the male participants rejected the practice because of a belief that female circumcision erodes females' sexual feelings. Many male respondents noted that circumcised women do not have any sexual feeling.

In Somalia dislike female circumcision, but they continue to perform it because of social pressures. Somalis in Norway and those in Somalia may both dislike female circumcision. But the environment they live in makes them different. If someone in Somalia does not circumcise their daughter, it may become an embarrassment to their entire family.

\section{Risk Medical in Somalia and Information Sexual Health}

For the research of Lindmark \& Dirie (1992) analyze about the risk of medical complications after female circumcision in Somali. In their research, there are 290 Somali women between the ages of 18-54. Thirty nine percent of the interviewed women had experienced significant complications after circumcision, most commonly hemorrhage, infection or urinary retention. Thirty-seven of the women reported a late complication of circumcision, these complications were dermoid cyst at the site of the amputated clitoris, urinary problems such as pain at micturition, dribbling urine incontinence and poor urinary flow. Forty of the women had experienced problems at the time of menarche and ten of them were operated because of haematocolpos. In Lindmark \& Dirie's research, female circumcision was first discovered in ancient Egyptian mummies in 200 B.C. In the preislamic era the custom was widespread in Egypt, Arabia and along the coast of the Red Sea. Nowadays it is practised in many African countries. Female circumcision is performed in three different ways:

The sunna type is analogous with male circumcision and consists of the excision of the prepuce of the clitoris.

The clitoridectomy type consists of the excision of the clitoris sometimes with parts of the minor labia.

The excision and infibulation operation means excision of the whole clitoris, the minor labia and the internal faces of the major labia. 
The mean age of the respondents was 2 years (range 18-54). Eighty-eight percent of the respondents were circumcised with excision and infibulation, while the remaining were circumcised with clitoridectomy $(6.5 \%)$ and sunna (5.5\%). Sixty-nine percent of the respondents were circumcised at home and 52\% of them were circumcised by an untrained person, mostly a traditional birth attendant (TBA).

The result of Lindmark's research shows that the medical complications endured by the women are both immediate and late. The immediate main complications as reported by 112 women were haemorrhage, local infection, urinary retention and septicaemia. The experienced haemorrhage was often significant. Five of the women reported getting into shock and two of them only recovered after being treated in hospital with blood transfusion.

One hundred and eight women of the sample studied experienced late complications of female circumcision such as pain at micturition, clitoral cyst and poor urinary flow. The pain at micturition was recurrent, sometimes disappearing and appearing again. Most likely the pain was due to recurrent urinary infection. The women consulted physicians for these complaints and antibiotics were prescribed for them. This sometimes brought relief of the symptoms. Two women developed urethral stricture and were operated on. Thirty-six subjects complained of a cyst appearing at the site of the amputated clitoris and 29 had the cyst excised. Five of the subjects reported anxiety about the nature of the cyst and thought it might develop into a masculine organ such as a penis. Fifteen women reported poor urinary flow due to tight infibulations. All of them consulted a physician but no one accepted to be defibulated in order to get remedy to the problem.

One hundred fifteen of the women studied had reached fertile age at the time of the survey. Forty (14\%) of these women had experienced difficulty at the onset of menarche with painful menstruations or haematocolpos, and twenty-nine of them consulted a physician. Ten of those reported that they were surgically defibulated and the haematocolpos was evacuated.

The haemorrhage complicating circumcision often occurs because the operation is performed by untrained persons, who do not know how to achieve adequate haemostasis. The cut vessels are not ligated and no suturing done. The legs of the young girls are straightened and tied together to give haemostasis. This often fails, as reported by women in the study. If the operation is not being performed under aseptic conditions, it can result in local infection. Tetanus infection is not uncommon. But like other lethal complications is not possible to find in a retrospective study.

The risk of medical complications after female circumcision is very high as revealed by the present study. Complications which cause the death of the young girls must be a common occurrence especially in the rural areas where health services do not exist. But even in urban centres people hesitate to seek medical help for their complications or do not accept the help offered as shown by the present study. If documented during the weeks just after circumcision the medical complications would probably be still more severe than when reported by the women many years after the operation. Dribbling urine incontinence, painful menstruations, haematocolpos and painful intercourse are facts that Somali women have to live with--facts that strongly motivate attempts to change the practice of female circumcision.

Knowledge of female circumcision in Somali

To the best of our knowledge, the current study is the first to examine the attitude of Somali immigrants regarding the continuation or discontinuation of girls circumcision in Norway. The result shows that female circumcision, which was formerly considered a form of cleanliness and an essential religious requirement is now considered by Somali immigrants in Oslo as harmful, barbaric, and un-Islamic.

The same factors that were initially used to justify the continuation of the practice in Somalia are now used by the participants as good reasons for its abandonment. With the exception of one man, all of the participants agreed that there are no Godly laws that support the practice and that the practice is traditional and in conflict with Islamic principles. An improved knowledge regarding the religious aspects of female circumcision is being made in Norway. The existence of an enabling environment that is unfavorable for the continuation of female circumcision, as well as an improved knowledge of the health effects of the practice, is central to the observed rejection of female circumcision among Somali immigrants in Oslo.

Because of the unrepresentative nature of our sample, we cannot conclude that Somali immigrants in Oslo have changed their behavior toward female circumcision. But the most important finding in this study is the presence of parents in Oslo who publicly declared that they did not circumcise their daughters and that uncircumcised girls were proud of being uncut, which is called a "positive deviant group".

\section{Conclusion}

Based on the findings, Female as a part of society did not have any rights on their own self. Their life is depend on the tradition which sustain until present and will be continued for next generation. The tradition is often spread within the religious belief and vice versa. Therefore, the practice of female circumcision is still happening in three regions, including Surabaya, Bangkalan and Situbondo. These regions have its own backgrounds related to the legal practice of female circumcision. The understanding of the perpetrators toward health is supported by the presumption of culture that has been brought down from generations to generations. It further aggravates the condition of legal action within the community. Based on the applicable laws and 
regulations, the government has role to maintain the welfare of its citizens, by applying applicable regulations and regulating both in the social to cultural aspects. However, the act of FGC is a proof that the community is still legalizing the practice. Citizens are still not understand the regulations on female circumcision. Female circumcision or FGC is still implemented in some communities and supported by the community's and religious' leader even though it is prohibited by the Regulation of the Health Minister (PERMENKES) Number 6/2014. Hence it categorized as an illegal activity. In order to prevent or maintain the health of woman, the next generation should have understanding on female circumcision due to avoid some mistakes in implementation and communicate more to religious' leader. Moreover, to enhance and create a just and non-discriminatory community, regulations and information on gender equality need to be carried out to the community. The conditions of different communities require different legal handling. The law enforcement need cooperation with the community in order to implement gender equality. The Law in books, action and society should be implemented correctly to have justice environment and the absent of discrimination toward human rights violations and coercion.

\section{REFERENCES}

1. Afkhami, M. (2008). The Future of Women's Rights (Global Vision \& Strategies (J. Kerr, E. Sprenger, \& A. Symington, Eds.). London: Zed Books.

2. Farida, J., Elizabeth, M. Z., Fauzi, M., Rusmadi, R., \& Filasofa, L. M. K. (2017). Sunat pada Anak Perempuan (Khifadz) dan Perlindungan Anak Perempuan di Indonesia: Studi Kasus di Kabupaten Demak. SAWWA, 12(3).

3. Fauziyah, S. (2017). Tradisi Sunat Perempuan di Banten dan Implikasinya terhadap Gender, Seksualitas, dan Kesehatan Reproduksi. Tsaqôfah: Jurnal Agama Dan Budaya, 15(2).

4. Feillard, A., \& Marcoes, L. (1998). Female Circumcision in Indonesia : To " Islamize " in Ceremony or Secrecy. Archipel, 56(337-367).

5. Hakim, C. (2016). The Sugar in His Tea: Sexuality, Patriarchy, and Sexual Politics. Sociologia, 3. https://doi.org/10.2383/85805

6. Imelda, J. D., Djamilah, D., Kartikawati, R., Mahendro, A. Y., \& Ratri, S. D. (2018). Elimination of Female Genital Circumcision in Indonesian Transition Society: Revealing a Hope. KnE Social Sciences, 3(10), 427. https://doi.org/10.18502/kss.v3i10.2925

7. Lestari, F. (2015). Seks, Gender, dan Konstruksi Sosial. Retrieved from Jurnal Perempuan website: https://www.jurnalperempuan.org/wacana-feminis/seks-gender-dan-konstruksi-sosial

8. Nantabah, Z. K., Laksono, A. D., \& Tumaji, T. (2015). DETERMINAN ORANG TUA DALAM PERILAKU SUNAT ANAK PEREMPUAN DI INDONESIA (Determinants of Parents for Female Children Circumcision in Indonesia). Buletin Penelitian Sistem Kesehatan, 18(1). https://doi.org/10.22435/hsr.v18i1.4273.77-86

9. Natsir, L. M. (2003). Mempertanyakan Praktik Sunat Perempuan di Indonesia. Retrieved from Harian Kompas website: http://www.mitrainti.org/?q=node/191

10. Negara, M. O. (2005). Mengurai Persoalan Kehidupan Seksual dan Reproduksi Perempuan. Jurnal Perempuan.

11. Nurdiyana, T. (2010). Sunat Perempuan pada Masyarakat Banjar di Kota Banjarmasin. Jurnal Komunitas, 2(2)

12. Pasaribu, V. A. . (2006). Kesetaraan dan Keadilan Gender. Universitas HKBP Nommensen.

13. Putranti, B. D. (2005). Sunat Perempuan: Cermin Bangunan Sosial Seksualitas Masyarakat Yogyakarta dan Madura. Jurnal Kependudukan Dan Kebijakan, 16(1).

14. Rachmadewi, R. (2000). Studi Evaluasi Pelaksanaan Program Kesetaraan dan Keadilan Gender (KKG) Sektoral di Tingkat Pusat, Propinsi Jawa Timur dan Sumatera Barat.

15. Ramli, L. (2019). Human Rights Approach in Environment Law Enforcement based on Law Number 23/2009. Research, Society and Development, 8(10). https://doi.org/10.33448/rsd-v8i10.1417

16. Sakti, Y. (2004). Sunat Anak Perempuan pada Masyarakat Urban Madura di Surabaya. Jurnal Penelitian Dinamika Sosial, 5(1).

17. Santi, S. (2006). Khitan Perempuan: Legitimasi Agama dan Budaya atas Kekerasan dan Pengendalian Tubuh Perempuan. Forum Ilmiah Indonesia, 3(1).

18. Smita, P. S. (2013). Sunat Perempuan, Melindungi atau Melukai? Retrieved from Femina website: https://www.femina.co.id/trending-topic/erempuan--melindungi-atau-melukai-

19. Trianto, T. (2012). Relasi Gender dalam Bingkai Budaya Cablaka. Yinyang, 7(2).

20. Umar, N. (1999). Argumen Kesetaraan Gender, Perspektif Al-Quran. Jakarta: Paramadina.

21. Umriana, A., Fauzi, M., \& Hasanah, H. (2016). Penguatan Hak Asasi Perempuan dan Kesetaraan Gender melalui Dialog Warga. SAWWA, 12(1), 41-59. 